DOI:

\author{
Оксана Марчук, кандидат педагогічних наук, доцент, \\ дочент кафедри педагогіки ПВНЗ “Міжнародний економіко-гуманітарний \\ університет імені академіка С. Дем'янчука”
}

\title{
ОСНОВНІ ТЕНДЕНЦІЇ НАВЧАННЯ ТА ВИХОВАННЯ ДІТЕЙ І МОЛОДІ В ОСВІТНЬО-КУЛЬТУРНИХ УСТАНОВАХ ВОЛИНСЬКОЇ ГУБЕРНІЇ
}

У статті досліджено специфіку навчання і виховання дітей та молоді в освітньо-культурних установах, щзо діяли на території Волинської губернії. Обгрунтовано, щзо навчання здійснювалося з урахуванням принципів науковості, доступності, системності, зв 'язку теорії із життям. Пояснено, щэо виховання сприяло формуванню християнських та моральних чеснотах. Зазначено, щзо до прочесу навчання $і$ виховання молоді активно долучалися представники місцевого духовенства та інтелігенції. Позитивною тенденцією визначено надання права здобувати освіту дітям, незалежно від їх віросповідання та батьківського достатку.

Ключові слова: тендениї; навчання; виховання; освітньо-культурна установа.

Puc. 1. Лim. 11.

Oksana Marchuk, Ph.D.(Pedagogy), Associate Professor of the Pedagogy of Private Higher Education Establishment "Academician Stepan Demyanchuk International University of Economics and Humanities"

\section{THE BASIC TRENDS OF THE EDUCATION AND UPBRINGING OF CHILDREN AND YOUNG PEOPLE IN EDUCATIONALAND CULTURAL INSTITUTIONS OF VOLYN PROVINCE}

The article shows the main trends of studying and upbringing of children and young people in the educational and cultural institutions of the Volyn Governorate. It is said that the aducational system was based on the principle of science, accessibility, systematicity. It is noted that upbringing was based on Christian morality. It is indicated that representatives of the priesthood and intellectual took part in the educational process of youth. A positive trend was the opportunity to get education for rich and poor children and also for the representatives of different religions.

The analysis of historical and pedagogical documents had shown that in the Volyn region there were a lot of educational traditions which can be used by nowadays teachers.

The purposes of the article is to analyze of the main trends of the studying and up-bringing of children and young people in the cultural and cultural institutions of the Volyn province.

Learning the basis of the studied lexemes the author gives an own (author's) definition of the tendencies of education and upbringing: they are the basic directions and the patterns of development of pedagogical ideas for giving knowledge and the formation of young generation outlook in a certain historical period in a certain territory.

The following main trends of education and upbringing in Volyn province are identified:1) the involvement of all social groups and religions in the process of education and upbringing of children and young people; 2) the formation of scientific worldview, the submission of the reliable information with the achievement of the science and technology; 3) the using in the educational process the principles of the consciousness, the accessibility, the clarity; 4) the introduction of health-saving technologies in the education and upbringing process; 5) the emphasis on the religious education, the promotion of Christian and moral values among children and young people.

However there were negative trends: there were not enough schools and that was why many children did not visit schools, especially in the villages; the lack of good educated staff in the activity of the cultural institutions; the lack of the financial sanctification of education; the Russification character of education and the ignoration of the national element in the up-bringing; the Russification character in contents of the textbooks and the didactic materials.

In the nowadays period of globalization and European integration the focusing on the best pedagogical models of the past and the promoting pedagogical achievements help to represent Ukraine in the world educational space in a good way.

Keywords: trends; training; an education; an educational and cultural institution.

П остановка проблеми. Вивчення педагогічних здобутків минулого сприяє покращенню навчальновиховного процесу у сучасних школах. Для цілісного осмислення кращих надбань українських учених та вчителів доцільно вивчати шкільництво окремих регіонів. Аналіз істрико-педагогічних документів засвідчив, що на Волині упродовж віків було вироблено своєрідні освітянські зразки, що можуть слугувати прикладом для нинішніх педагогів. Необхідність вивчення педагогічного досвіду освітян минулих століть обумовлена такими факторами: а) реформуванням цілої системи освіти України відповідно до 
міжнародних стандартів в умовах євроінтеграції та глобалізації; б) впровадженням концепції Нова українська школа; в) виникненням нових освтньокультурних центрів; г) поступовим занепадом моральних, духовних, сімейних цінностей та зростомзлочинності середпідлітків; д) запровадженням курсів християнської етики в школах. Це зазначено у Національній доктрині розвитку освіти, де зроблено акцент на “вихованні особистості, яка усвідомлює свою належність до Українського народу, сучасної європейської цивілізації, орієнтується в реаліях і перспективах соціокультурної динаміки" [5].

Аналіз останніх досліджень та публікацій. Окремі тенденції навчання та виховання дітей і молоді на Волині вивчали науковці різних епох. У кінці XIX - на початку XX століття освіту дослідженого регіону аналізували І. Барсов, П. Батюшков, А. Глаголовський, М. Грушевський, Д. Дорошенко, І. Крип'якевич, М. Костомаров, О. Левицький, І. Огієнко, С. Рождественський, Я. Перлштейн, А. Пругавін, М. Теодорович. Розвиток освіти в незалежній Україні був об'єктом дослідження О. Білецького, Л. Вовк, С. Гаврилюк, О. Глузмана, М. Свтуха, М. Левківського, Л. Медвідь, О. Любара, Л. Редькіної, Т. Стоян, М. Стельмаховича, О. Сухомлинської. Певні аспекти навчання та виховання дітей і молоді в закладах Волинської губернії частково проаналізовано в наукових розвідках О. Борейка, С. Бричок, О. Буравського, Н. Бовсунівської, Т. Джаман, Л. Ершової, С. Коляденко, Р. Найди, В. Омельчука, Н. Сейко.

Мета статті - проаналізувати основні тенденції навчання і виховання дітей та молоді в освітньо-культурних установах Волинської губернії.

Виклад основного матеріалу. У XIX ст. Волинська губернія входила до складу Російської держави. Засадчими для нашої статті є терміни тенденція, навчання та виховання. У довідниковій літературі подано тлумачення цієї лексеми. У “Новому словнику іншомовних слів" пояснено, що тенденція - це напрям розвитку якого-небудь явища; прагнення, схильність, властиві кому-н. або чому-н.” [11, 590]. Укладачі “Великого тлумачного словника сучасної української мови” цим терміном позначають „потяг, схильність до чогось; провідну думку; ідейне спрямування; напрям розвитку чогонебудь” [1, 1238]. В “Українському педагогічному енциклопедичному словнику” автором подано таке визначення лексеми виховання: “процес цілеспрямованого, систематичного формування особистості, зумовлений законами суспільного розвитку, дією багатьох об'єктивних i суб'єктивних факторів; сума впливів на психіку людини, спрямованих на підготовку іiї до активної участі у виробничому, громадському й культурному житті суспільства" $[3,71]$. Він також дав пояснення навчанню - “цілеспрямований процес передачі і засвоєння знань, умінь, навичок і способів пізнавальної діяльності” $[3,303]$.

На основі досліджених лексем дамо власне (авторське) визначення тенденцій навчання та виховання, під якими, на нашу думку, слід розуміти основні напрями та закономірності розвитку педагогічних ідей щодо передачі знань та формування світогляду підростаючого покоління в певний історичний період на визначеній території. На території Волинської губернії у XIX - на початку XX ст. склалася система установ, які надавали освітні послуги населенню (рис. 1).

Аналіз сучасної науково-педагогічної літератури, архівних матеріалів про навчальні заклади Волині XIX - початку XX століття, статей iз тогочасних періодичних видань дозволив виокремити позитивні тенденції навчання та виховання дітей і молоді у освітньо-культурних установах, що склалися у Волинській губернії. Нами були виокремлено такі закономірності навчального процесу:

1. Залучення до процесу навчання $і$ виховання дітей і молоді усіх суспільних верств населення та віросповідання: У освітньо-культурних установах надавали можливість навчатися та займатися різними видами виховної діяльності дітям, незалежно від матеріальних статків їх батьків та віросповідання. Так, серед учнів Острозької чоловічої гімназії станом на 1 січня 1909 року навчалося 394 учні. Найбільшу кількість становили представники православ'я - 58,1%, найменше було протестантів - 0,5 \%.

Серед гімназистів були діти різноманітних груп населення Волині: більшість учнів були дітьми корінних дворян $(17,5 \%)$, чиновників $(24,9 \%)$ та міщан $(21,5 \%)$, найменше - козаків $(0,3 \%)$ та іноземних громадян ( $2 \%$ ). Варто акцентувати увагу на тому, що діти заможних селян також мали змогу відвідувати гімназію: у 1908-1909 н. p. вони становили 18 \% від загальної кількості учнів $[7,13]$.

2. Формування наукового світогляду, подача достовірної інформації із досягненням тогочасних надбань науки і техніки: Волинські педагоги та діячі культурних установ намагалися ознайомити дітей і молодь із досягненнями тогочасних вчених в різних галузях науки. Так, тогочасні підручники і посібники містять достовірну, науково перевірену інформацію. В освітньому процесі вчителі ознайомлювали дітей 


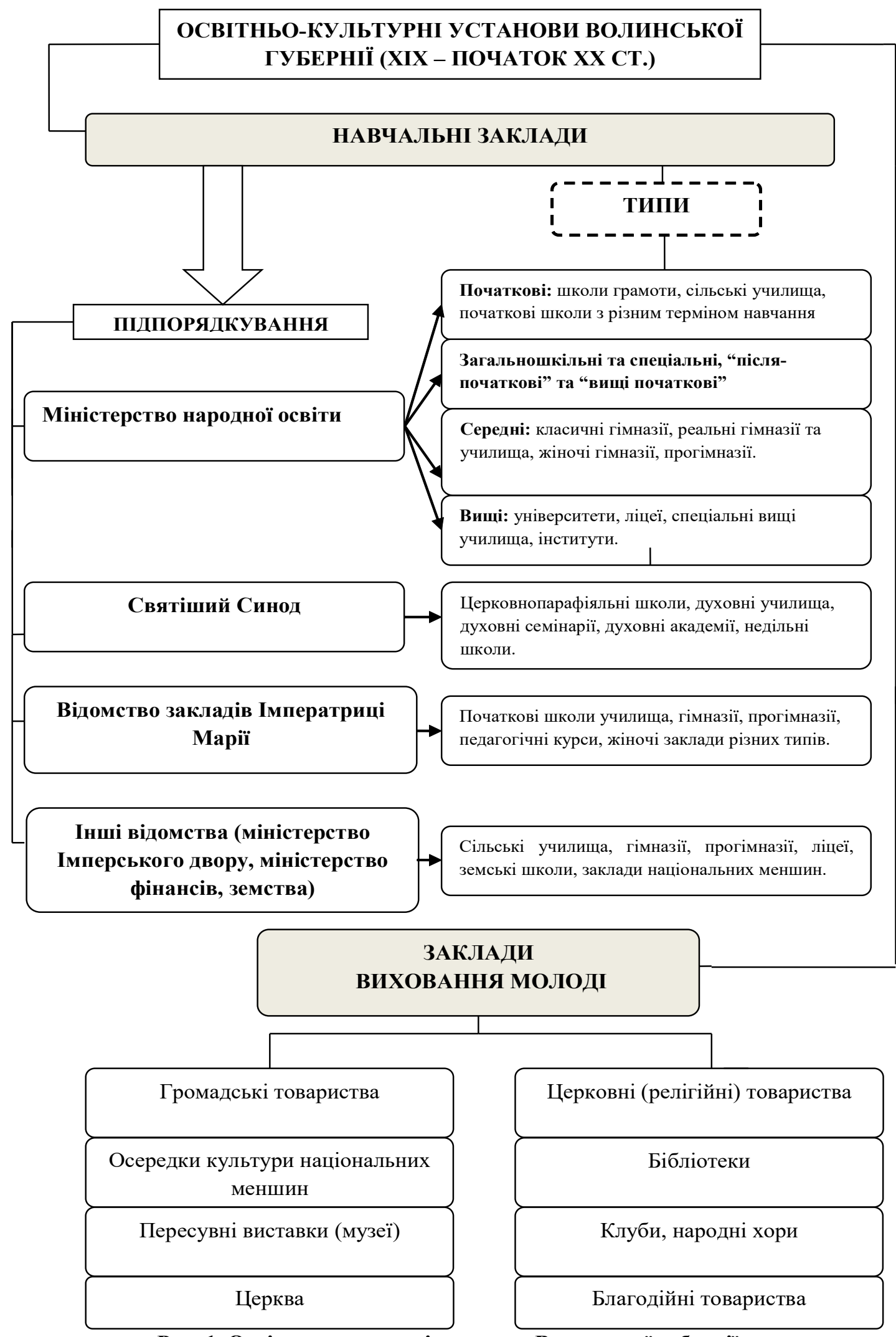

Рис. 1. Освітньо-культурні установи Волинської губернії 
iз роботою нових механізмів. Наприклад, у гімназіях волинського регіону були окремі кабінети для вивчення навчальних предметів. Гордістю Острозької чоловічої гімназії був кабінет фізики, матеріально-технічна база якого складалася із 345 предметів: “Із особливо вагомих покупок 1909 р. можна відмітити електричну машинку Вімгорста та сучасні терези" [7, 4].

Активісти громадських товариств та церковних братств проводили бесіди з молоддю, де оповідали про історію Волині, розвиток православ'я, надавали відомості із фізики, астрономії, географії.

3. Використання в освітньому процесі принципів свідомості, доступності, наочності: Вчителі Волинської губернії намагалися доступно пояснити навчальний матеріал. Вони повинні були “пояснювати учням невідомі слова і вирази” [6, 3]. Як зазначено у “Статуті православних духовних семінарій”, якими послуговувалися викладачі Волинської духовної семінарії, “методи викладання повинні були допомагати правильному розвитку природних обдарувань і викликати власну діяльність розумових сил учнів, але так, щоби пам'ять не була перенавантажена без потреби і нічого не варто запам'ятовувати без глибинного розуміння суті” $[9,86]$. Кабінети навчальних закладів географії, біології, образотворчого мистецтва мали велику кількість належних атласів, глобусів, карт, експонатів для малювання, таблиць, демонстраційних матеріалів, експонатів, гербаріїв.

Правильно підібрані методи, форми і прийоми навчання спряли тому, що школярі волинського регіону демонстрували належні успіхи при складання іспитів. Повідомлення про це вміщено в статтях про експонати на Всеросійську церковно-шкільну виставку в Санкт-Петербурзі. Так, архівні джерела свідчать, що “діти Острозького повіту сьогодні вільно вирішують математичні задачі 3 простими і іменними числами не лише усно чи на класній дошці, але й письмово в зошитах, детально пояснюючи хід розв'язання; із мови правильно пишуть не лише диктанти, але й перекази статей; церковний спів в багатьох наших школах викладається зразково (взірцево), створені дитячі прекрасні церковношкільні хори, які можуть співати в міських соборах" $[4,86]$.

Прикладом належної організації освітнього процесу в школах Волинської губернії може слугувати Острозька чоловіча гімназія Міністерства народної освіти, де в 1908 - 1909 н. p. кількість учнів, які демонстрували належний рівень знань із усіх предметів сягала $63 \%$ [7, арк. 15].
4. Використання здоров'язберігаючих технологій nід час навчання і виховання дітей: У педагогіці під поняттям “здоров’язберігаюча технологія навчання” розуміють систему заходів, спрямованих на формування, збереження та покращення здоров'я школярів, створення сприятливих та безпечних умов для навчання, організація правильного режиму праці, відпочинку та харчування школярів, дотримання санітарногігієнічних норм, проведення медоглядів, пропагування здорового способу життя тощо. Робота навчальних закладів Волинської губернії була спрямована на виховання фізично здорової учнівської особистості. Вчителі волинських навчальних закладів влітку щороку ретельно готували приміщення до опалювального сезону, стежили за чистотою та охайністю учнів, провітрювали приміщення, ходили на прогулянки під час класних занять і в позаурочний час.

У періодиці друкували статті відомих волинських педіатрів про правильний режим школяра, харчування учнів заходи під час епідемій тощо. На цю тему, наприклад, були написані такі статті: “Доповідь лікаря, що завідує лікарнею Волинської духовної семінарії, Дивізійного Доктора II Дивізії М. Глоголи на ім'я його Первосвященства від 28 червня 1869 р.”, “Замітка про шкідливий вплив куріння на організм хлопчиків", “Про високе значення матері". Пропагування здоров'язбергігаючих технологій спостерігаємо і в доповідях активістів волинських громадських організацій, церковних братств i товариств у м. Дубно, Кременець, Старокостянтинів, Луцьк, Рівне.

5. Акцент на релігійному вихованні, пропагування християнських та моральних иінностей серед дітей та молодi: Аналіз роботи навчальних закладів, громадських товариств, бібліотек досліджуваного періоду засвідчив, що дітей i молодь волинського регіону в XIX - на початку $\mathrm{XX}$ століття виховували в християнському релігійному дусі. Про це свідкують такі факти: a) Закон Божий був обов'язковим навчальним предметом; б) місцеві священики залучалися до проведення занять у школах; в) діти брали активну участь у богослужіннях, шкільні хори співали на Службі Божій; г) виховні заходи мали яскраво виражену християнську релігійну тематику; д) до освітнього процесу, окрім священиків, долучалися представники церковних братств. Серед розпоряджень тогочасного Єпархіального Наглядача до керівництва шкіл, наприклад, знаходимо документи такого змісту: "Прошу посприяти тому, щоб діти усіх шкіл співали в церкві, i, якщо не зуміють відразу співати 


\section{ОСНОВНІ ТЕНДЕНЦЇ̈ НАВЧАННЯ ТА ВИХОВАННЯ ДІТЕЙ ІМОЛОДІ В ОСВІТНЬО-КУЛЬТУРНИХ УСТАНОВАХ ВОЛИНСЬКОЇ ГУБЕРНІЇ}

всі, то хоча би спочатку виконували лише окремі пісноспіви" [8, арк. 15].

Християнські та моральні цінності пропагувалися також у змістовому наповненні навчальних підручників та посібників. У волинських школах навчання правопису здійснювалося за підручниками А. Зачиняєва, Ф. Пуцинковича, Д. Тихомирова, читання М. Лебедева, М. Пуцила, математики М. Вальцева, I. Верещагіна, А. Гольденберга, П. Цветкова, історії - А. Добрінина, географії А. Баркова, С. Григор'єва, А. Креберга, креслення - В. Акімова. Чимало текстів “Азбуки правопису” розповідали про обов'язки людини щодо ближнього, порушували питання віри у Бога, навчали поваги, любові, доброзичливості: $\mathrm{Ha}$ человеке лежат обязанности к самому себе, обязанности к ближнему, еще государственные или гражданские, и, наконеи, духовне (рос.) [10, 15]. У хрестоматії "В рідному світі”" М. Пуцила діти читали оповідання "Монастир”, “Світле воскресіння", "В святу ніч”, “Могила сина". Справжнього християнського милосердя навчали новели із "Рідної мови" ("Голос совісті", “Сирітка", “Допомога в біді", “Правда і кривда”). Морально-етична тема яскраво представлена не лише у читанках, а й у підручниках із математики. Окремі завдання мали на меті виховати співчуття, співпереживання, готовність допомогти ближньому.Наприклад, ““Збірникузадач”М.Вальцева подано задачі такого змісту: В обществе, состоящим из 12 лиц, был сделан сбор в пользу бедных, каждый мужчина внес по 6 руб., а женщина - по 2 руб., всего собрали 54 руб. Сколько было мужчин и женщин? (рос.) $[2,94]$.

Однак, в зазначений період виокремлюються певні негативні тенденції: недостатня кількість шкіл та охопленість навчанням дітей, особливо у сільській місцевості; недостатнє забезпечення діяльності освітньо-культурних установ досвіченими кадрами; недостатнє фінансування освітньої галузі; русифікаторський характер освіти та нівелювання національним елементом у вихованні; проросійський характер та зміст навальних підручників та дидактичних матеріалів.

Висновки. Отже, у XIX - на початку XX століття на території Волинської губернії функціонували різні типи освітньо-культурних установ. Найбільш поширеними серед них були церковнопарафіяльні школи, громадські товариства та церковні братства, вчителі та діячі яких здійснювали процес навчання та виховання дітей i молоді. В освітньому процесі використовували доцільні методи та прийоми навчання, здоров'язберігаючі технології, пропагували християнські та моральні цінності, залучали духівництво та інтелігенцію до просвітницького руху.

В умовах глобалізації та євроінтеграції орієнтація на кращі педагогічні зразки минулого та пропагування педагогічних здобутків допомагає кращому представленню України у світовому освітньому просторі.

\section{ЛIТЕРАТУРА}

1. Бусел В. Т. Великий тлумачний словник сучасної української мови Київ, 2004. 1440 с

2. Вальцев Н., Шапочников Н. Сборник алгебраических задач. Москва-Петроград, 1916. 192 с.

3. Гончаренко С. Український педагогічний енциклопедичний словник. Рівне, 2011. 552 с.

4. Експонати на всеросійську церковно-шкільну виставку від Острозького повіту. Волинські Спархіальні Вiдомості. 1909. Частина офіційна. № 15. С. 309-313.

5. Національна доктрина розвитку освіти. URL: infolibrary.com.ua (дата звернення: 17.10.2019).

6. Невзорова Н. Сборник статей из образцовых призведений русской словесности. Санкт-Петербург. Часть 1. 1913. № 19. 124 c.

7. Острозька чоловіча гімназія міністерства народної освіти, м. Острог, Волинська губернія. ДАРО, ф. 555, оп. 1, спр. 1, 32 арк.

8. Розпорядження єпархіального начальства завідувачам церковнопарафіяльними школами Житомирського повіту. Волинські єпархіальні відомості. 1909. Частина офіційна. № 5. С. 55.

9. Статут православних духовних семінарій. Волинські єпархіальні відомості. 1867. Частина офіційна. № 3. С. 76-104.

10. Тихомиров Д. Азбука правописания. Москва, $1897.89 \mathrm{c}$.

11. Шевченко Л., Ніка О., Хом'як О. Новий словник іншомовних слів. Київ, 2008. 672 с.

\section{REFERENCES}

1. Busel, V. T. (2004). Velykyi tlumachnyi slovnyk suchasnoi ukrainskoi movy [A great explanatory dictionary of modern Ukrainian]. Kyiv. 1440 p. [in Ukrainian].

2. Valtsev, N. \& Shapochnykov, N. (1916). Sbornyk alhebraycheskykh zadach [Collection of algebraic problems]. Moskva-Petrohrad, 192 p. [in Russian].

3. Honcharenko, S. (2011). Ukrainskyi pedahohichnyi entsyklopedychnyi slovnyk [Ukrainian Pedagogical Encyclopedic Dictionary]. Rivne, 552 p. [in Ukrainian].

4. Eksponaty na vserosiisku tserkovno-shkilnu vystavku vid Ostrozkoho povitu (1909). [Exhibits at the all-Russian church-school exhibition from Ostroh county]. "Volynski Yeparkhialni Vidomosti". Official part. No. 15, pp. 309-313. [in Russian].

5. Natsionalna doktryna rozvytku osvity [National doctrine of educational developmenteducation]. Available at: info-library.com.ua. (accessed 17 Nov. 2019). [in Ukrainian]. 
6. Nevzorova,N. (1913). Sbornyk statei yz obraztsovikh pryzvedenyi russkoi slovesnosty [Collection of articles from exemplary casts of Russian literature. SanktPeterburh]. Part 1. No.19. 124 p. [in Russian].

7. Ostrozka cholovicha himnaziia ministerstva narodnoi osvity, m. Ostroh, Volynska huberniia [Ostrog Men's Gymnasium of the Ministry of Public Education, Ostroh, Volyn province]. DARO, f. 555, op. 1, spr. 1, 32 p. [in Ukrainian].

8. Rozporiadzhennia yeparkhialnoho nachalstva zaviduvacham tserkovnoparafiialnymy shkolamy Zhytomyrskoho povitu. (1909). [Order of the diocesan administration to the heads of parish schools of Zhytomyr county]. "Volynski yeparkhialni vidomosti”. Official part. No. 5, p. 55. [in Russian].

9. Statut pravoslavnykh dukhovnykh seminarii (1867). [Charter of Orthodox Theological Seminary]. "Volynski yeparkhialni vidomosti". Chastyna ofitsiina. No. 3. pp. 76-104. [in Russian].

10. Tykhomyrov, D. (1897). Azbuka pravopysanyia. [Spelling alphabet]. Moscov, 89 p. [in Russian].

11. Shevchenko, L., Nika, O. \& Khomiak, O. (2008) [Novyi slovnyk inshomovnykh sliv New Dictionary of Foreign Language Words]. Kyiv, 672 p. [in Ukrainian].

Стаття надійшла до редакції 11.01.2020

UDC 378.147

DOI:

Yuliya Kornytska, Ph.D.(Pedagogy), Associate Professor of the English Language for Humanities № 3 Department National Technical University of Ukraine "Ihor Sikorskiy Kyiv Polytechnic Institute"

\section{FLIPPED CLASSROM IN THE ESP COURSE: STUDENTS' PERCEPTIONS}

The peculiarities of the new ESP curricula impose educators to refocus their teaching strategies and adopt new approaches to meet the challenges, incorporate facilitative technologies and to provide models and opportunities for effective and ample practical work. In this context, the flipped classroom approach is getting more and more attention from practitioners and researchers. However, reporting positive evidences of employing flipped classroom approach in language training, the researchers emphasise the close interrelation between learning outcomes and positive acceptance. Activities accepted as interesting and useful could function as mediators to increase students' motivation, develop and deepen their interest and knowledge. On the contrary, activities that are inconsistent with students' preferences and interests might result in demotivation, increased anxiety and absenteeism. Since students' preferences for training activities and approaches are associated with motivation factors and have a direct bearing on the learning outcomes, choices in training are to be influenced by students' perceptions and considered in this context.

The manuscript aims to present the results of the research on students' attitudes toward flipped class elements in traditional curricula. The obtained results support the assumption that the approach has a great potential to affect the ESP class positiely. When used appropriately, flipped class elements can foster students'engagement in the learning process, which many students find beneficial and as the research has shown to decrease attrition, enhance students ' positive attitude and motivation, improve students' satisfaction.It is compatible with the regular curriculum and has a good potential to reform the traditional time-consuming in-class components of the ESP course and make it more topical and motivating. However, the process of implementing new formats of training requires not only careful planning, but also monitoring the students' feedback.

Keywords: flipped class; ESP; advantages; survey; students.

Table. 1. Ref. 6.

Юлія Корницька, кандидат педагогічних наук, доцент кафедри англійської мови гуманітарного спрямування № 3

Національний технічний університет Украйни

“Київський політехнічний інститут імені Ігоря Сікорського”

\section{ПЕРЕВЕРНУТИЙ КЛАС В КУРСІ АНГЛІЙСЬКОЇ МОВИ ФАХОВОГО СПРЯМУВАННЯ: СТАВЛЕННЯ СТУДЕНТІВ}

У статті розглядається потенціал підходу “Перевернутий клас" для ефективної організації процесу навчання англійської мови фахового спрямування. На основі теоретичного аналізу актуальних досліджень представлено узагальнений перелік переваг використання підходу. Оскільки важслиою передумовою ефективного впровадження є позитивне сприйняття, метою дослідження було виявити ставлення студентів до запропонованого підходу. Отримані результати підтвердили, щэо обтрунтоване використання елементів 